\title{
Left Ventricle Myocardium Volume Densities in Spontaneously Hypertensive Rats (SHR) Following Combination of Exercise and ACE Inhibitor Treatment. A Stereological Study
}

\author{
Densidad de Volumen del Miocardio del Ventrículo Izquierdo en Ratas Espontáneamente Hipertensas \\ (REH) Posterior a la Combinación de Ejercicios y Tratamiento Inhibidor de la ACE. Estudio Estereológico
}

"Inuwa, I. M.; "Hassan, M. O. \& **Ziada, A. M.

INUWA, I. M.; HASSAN, M. O. \& ZIADA, A. M. Left ventricle myocardium volume densities in spontaneously hypertensive rats (SHR) following combination of exercise and ACE inhibitor treatment. A stereological study. Int. J. Morphol., 23(2):157-162, 2005.

SUMMARY: This study was designed to test the possible effects of a combination of physical and pharmacological therapy intervention on myocardial structure of the left ventricle in spontaneously hypertensive rats (SHR).

Twelve weeks old spontaneously hypertensive rats $(\mathrm{n}=40)$ were divided into four groups of sedentary, (Sed) as controls, exercise only (Exer), lisinopril only $20 \mathrm{mg} / \mathrm{kg} /$ day (Lis), and exercise + lisinopril (LisExer). Exercise training was performed on a treadmill (5m/ min.) for 60 minutes/day, 5 days/week for 10 weeks. At the end of 10 weeks, all the rats were terminally anaesthetised, the heart was arrested in diastole by intravenous procaine and whole animal perfusion fixation through the abdominal aorta was carried out using Karnovsky's fixative ( $\mathrm{pH}$ 7.24). The heart was removed and left ventricle plus the interventricular septum was serially sectioned at a thickness of $3 \mathrm{~mm}$. One piece was randomly chosen, and embedded in JB4 resin. Six sections were obtained from each block, stained with toluidine blue:acid fucin. Measurement of volume fraction (Vf), of myocardium, capillaries and interstitium were carried out using a stereology software (Histometrix MIL6 Kinetic imaging Ltd.).

Mean $\mathrm{V}_{\mathrm{f}}$ of capillaries in Sed group was $0.114 \pm 0.01$ (SEM). This was significantly increased in LisExer group. The $\mathrm{V}_{\mathrm{f}}$ of muscle in Sed group was $0.795 \pm 0.02$ (SEM). This was significantly decreased in Lis but unchanged in Exer group. Capillaries $\mathrm{V}_{\mathrm{f}}$ was significantly higher in LisExer as compared to Lis or Exer groups $(\mathrm{p}<0.05)$. Muscle $\mathrm{V}_{\mathrm{f}}$ was not different between LisExer and Lis groups. The outcome of these changes could well be a better enhancement of cardiac performance in hypertension by combined exercise and ACE inhibitor treatment than either of the interventions alone.

KEY WORDS: Myocardium; Hypertrophy; ACE-inhibitor; Volume fraction; Exercise.

\section{INTRODUCTION}

One of the non- pharmacological interventions used in the management of hypertension is moderate physical exercise. Moderate exercise is considered as a useful tool in reducing blood pressure and is often prescribed to hypertensive patients in addition to drug treatment (Mancia et al., 1999). Some studies indicated that moderate exercise increase left ventricular hypertrophy in rats and that the beneficial effect of exercise on hypertension is through the improvement in coronary micro vasculature (Anversa et al., 1983; Crisman \& Tomanek, 1985). Moderate exercise has been shown to also induced myocardial capillary growth in the spontaneously hypertensive rat (Crisman \& Tomanek) Others have suggested that moderate exercise in humans reduces left ventricular hypertrophy (Himeno et al., 1996; Hinderliter et al., 2002).

The renin-angiotensin-aldosterone system (RAAS) plays a key role in the pathogenesis of certain types of hypertensive heart disease. Blockade of this system results in a number of biologically important beneficial effects including reduction in blood pressure as well as reversal of endothelial dysfunction (Lazar et al., 2001). Treatment with

\footnotetext{
* Department of Human and Clinical Anatomy, Sultan Qaboos University, Oman.

** Department of Physiology, Sultan Qaboos University, Oman.

Grant for this project provided by the Sultan Qaboos University research fund.
} 
ACE inhibitors reduce cardiac hypertrophy and improve coronary vascular reserve in left and right ventricles in hypertensive rats (Heringer-Walther et al., 2001). It is believed that such drugs are able to reduce myocardial hypertrophy by inducing selective apoptosis of cardiomyocytes and interstitial fibroblasts (Der Sarkissian et al., 2003).

One of the approaches of evaluating benefit of antihypertensive management is the assessment of reduction of myocardial hypertrophy. In humans, assessment of myocardial hypertrophy is usually done with the help of echocardiography.

An animal model of hypertension - the spontaneously hypertensive rats (SHR) is available where hypertension gets established by the age of 12 weeks. The main approach to the design of this experiment is that after experimental interventions in such animals the whole left ventricle can be obtained and by using unbiased stereology the volumes of various components of the myocardium can be obtained.

This study aims at evaluating the effect of both interventions of moderate exercise and ACE inhibitor treatment on left ventricular myocardium structure in spontaneously hypertensive rats. The hypothesis is that if ACE inhibitor treatment attenuates left ventricular hypertrophy and exercise improves ventricular vascular bed, then combining the two would lead to a better outcome with respect to reduction in myocardial hypertrophy and increased capillary volume. This could presumably improve myocardial performance better than either intervention alone.

\section{MATERIAL AND METHOD}

Experimental design. All procedures were in accordance with the principles for use of animals in research and education and approved by the medical research and Ethics Committee of the College of Medicine (MREC). Forty male spontaneously hypertensive rats (SHR) were kept in pairs and housed in a temperature controlled room $\left(23-25^{\circ} \mathrm{C}\right)$ with a 12 hour day/night cycle. Food and water were available $a d$ libitum until when they were 12 weeks old and systemic hypertension well established (average tail cuff systolic blood pressure recording was $205 \pm 5 \mathrm{mmHg}$ ).

At 12 weeks of age, the rats were randomly divided into four groups $(n=10)$; sedentary (Sed) as controls, exercise only (Exer), 20mg/kg/day lisinopril only (Lis), and combined exercise + lisinopril (LisExer). Exercise training was performed on a motor treadmill $(5 \mathrm{~m} / \mathrm{min}$.) for 60 minutes/day, 5 days/week, for 12 weeks. Lisinopril, an ACE inhibitor was administered daily intraperitoneally for 12 weeks.

Animal sacrifice and obtaining tissues. At the end of 12 weeks, each animal was weighed before induction of anesthesia. Thereafter, intraperitoneal injection of sodium pentobarbitone $(50 \mathrm{mg} / \mathrm{kg})$ was given. The abdomen was opened via a midline incision. Abdominal aorta and inferior vena cava were identified and canulated. Whilst the heart was still beating 1000 units of heparin was injected through the IVC to prevent blood clotting. After one minute of heparin injection, one milliliter of $2 \%$ procaine was injected also through the IVC, which stopped the heart beating in diastole. Through the aortic canula, $100 \mathrm{ml}$ of Karnovski's fixative was injected at a pressure of $160 \mathrm{mmHg}$ until the heart was fully perfused. Thereafter, the whole heart was removed weighed, and immersed in the same fixative for one hour. The left ventricle was excised weighed and serially sectioned into $3 \mathrm{~mm}$ pieces in a "small object slicer" filled with molten paraffin wax.

Estimation of volume fractions $\left(\mathbf{V}_{\mathrm{f}}\right)$. One slice of the ventricle was cut using the orientator method (Mattfeldt et al., 1990) so as to obtain an isotropic uniform random tissue face. This tissue face was embedded in JB4 resin and six 1.5 $\mu \mathrm{m}$ sections obtained on a microtome (Leica RM2145). The sections were stained with combined toluidine blue:acid fucsin (muscle appear blue while capillaries appear red). From each section, ten systematic random fields were sampled and estimates of volume fractions of capillaries, myocardium, and interstitial tissue obtained. This was carried out with the help of a stereology software (Histometrix MIL6 Ver 1.0, Kinetic Imaging Ltd. England) installed on an IBM personal computer.

All data was presented as mean \pm standard error of mean. Analysis of the data was by the use of analysis of variance (ANOVA) followed by Student-Newman-Keuls Multiple Comparisons post-hoc test. The selected criterion for statistical significance was when the two-tailed $\mathrm{p}$ value was less than 0.05 .

\section{RESULTS}

Mean $\mathrm{V}_{\mathrm{f}}$ of components of the myocardium is shown in Table I. Mean $\mathrm{V}_{\mathrm{f}}$ of capillaries was increased by $7 \%$ $(\mathrm{p}<0.01), 6 \%(\mathrm{p}<0.01)$ and 12\% $(\mathrm{p}<0.001)$ in the Lis, Exer, and LisExer groups, respectively. The $\mathrm{V}_{\mathrm{f}}$ of muscle has decreased $11.4 \%(\mathrm{p}<0.01), 3.3 \%(\mathrm{p}>0.05)$, and $16.5 \%$ $(\mathrm{p}<0.01)$ in the Lis, Exer, and LisExer groups, respectively. 


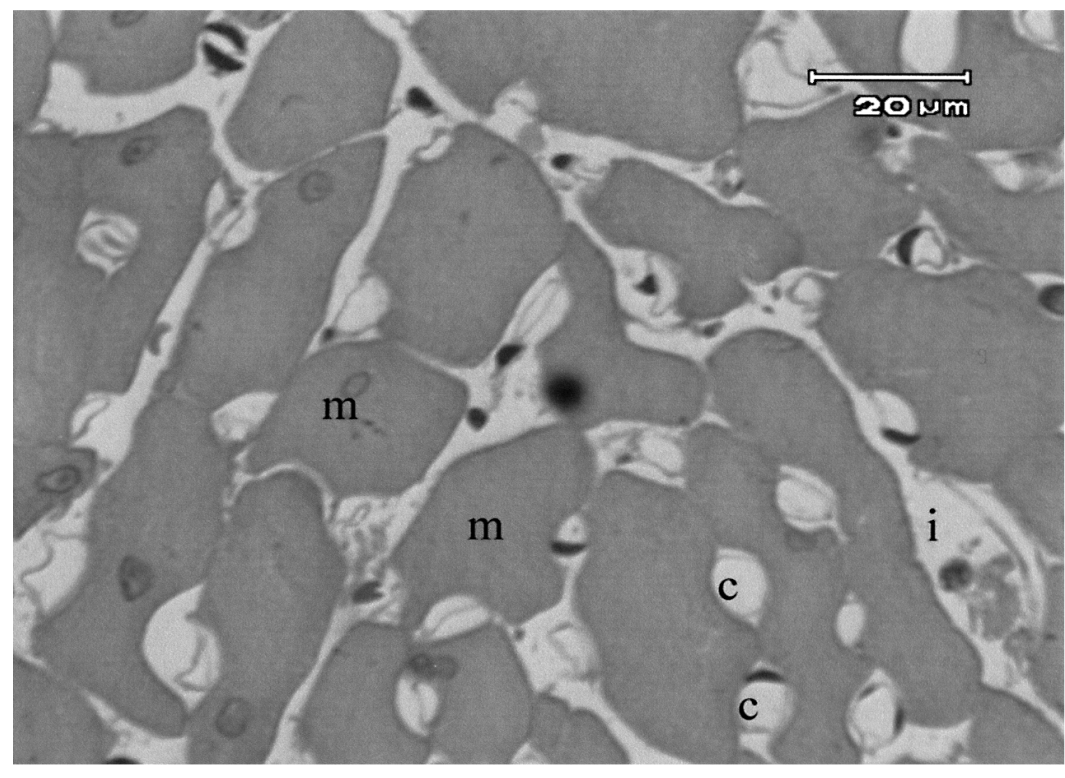

Volume fraction of interstitial tissue has decreased 3.8\%, and 3.9\% in Lis, and LisExer groups, respectively $(\mathrm{p}>0.05)$ whilst it was unchanged in the Exer group.

Lis group had significantly smaller $\mathrm{V}_{\mathrm{f}}$ of muscle when compared to Exer group $(\mathrm{p}<0.05)$. In LisExer group, $\mathrm{V}_{\mathrm{f}}$ of muscle was significantly smaller when compared to Exer group $(\mathrm{p}<0.001)$, although there was no significant difference when compared to Lis group (Figs. 2 a-c). Volume fraction of interstitial tissue was not significantly different ( $p>0.05$ ) between all experimental groups (Figs. 3 a-c). There was no significant difference in $V_{f}$ of capillaries between Lis and Exer group. LisExer had significantly higher $\mathrm{V}_{\mathrm{f}}$ of capillaries as compared to Lis and Exer groups $(\mathrm{p}<0.05)$ (Figs. 4 a-c $).$

Fig. 1. Photomicograph of left ventricle myocardium in SHR. Capillaries (c), muscle (m), interstitium (i).

Table I. Mean volume fraction of myocardium components in Sed, Lis, Exer, and LisExer groups.

\begin{tabular}{llll}
\hline & & \multicolumn{2}{c}{ Volume fraction, $V_{f}($ Mean \pm SEM $)$} \\
Group & Muscle & Capillaries & Interstitium \\
\hline Sed & $0.795 \pm 0.02$ & $\mathbf{0 . 1 1 4} \pm 0.01$ & $0.106 \pm 0.02$ \\
Lis & $0.681 \pm 0.02^{* *}$ & $\mathbf{0 . 1 8 0 \pm 0 . 0 1 * *}$ & $0.144 \pm 0.02$ \\
Exer & $0.762 \pm 0.02$ & $\mathbf{0 . 1 7 3} \pm 0.01^{* *}$ & $0.101 \pm 0.03$ \\
LisExer & $0.630 \pm 0.02^{* *}$ & $\mathbf{0 . 2 2 5 \pm 0 . 0 1 * * *}$ & $0.145 \pm 0.02$ \\
\hline$* * \mathrm{p}<0.01, * * * \mathrm{p}<0.001$ & & &
\end{tabular}

(a)

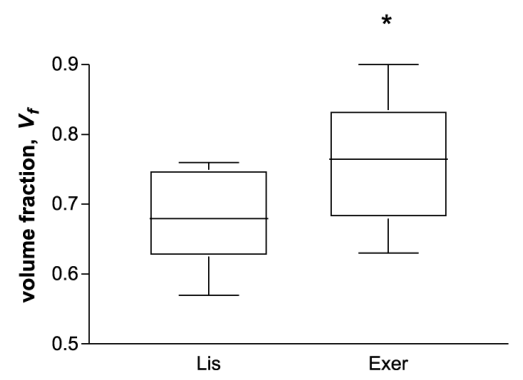

(b)

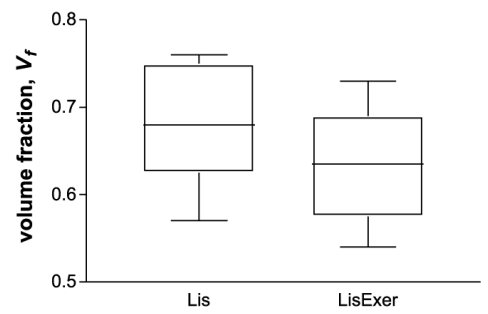

(c)

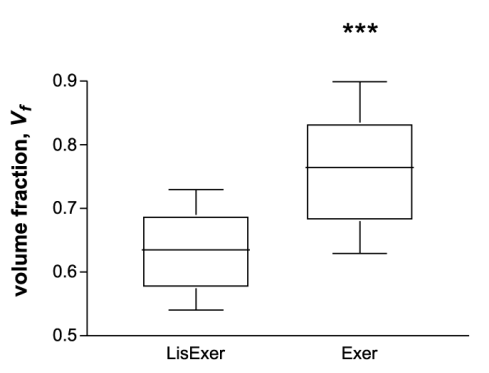

Fig. 2. Box plot comparison of $\mathrm{V}_{\mathrm{f}}$ muscle between intervention groups. (a) between Lis and Exer, (b) between Lis and LisExer, (c) between LisExer and Exer. $* \mathrm{p}<0.05, * * \mathrm{p}<0.01, * * * \mathrm{p}<0.001$

(a)

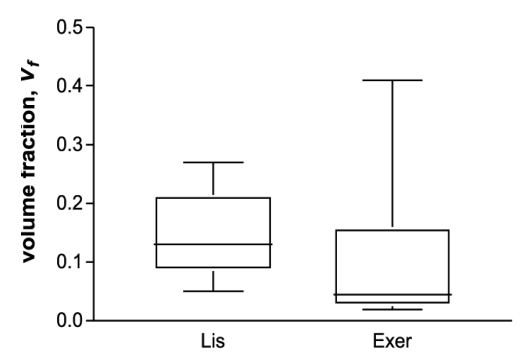

(b)

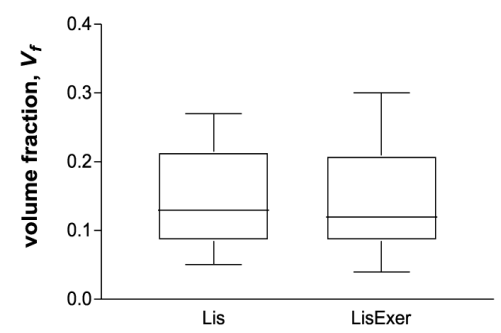

(c)

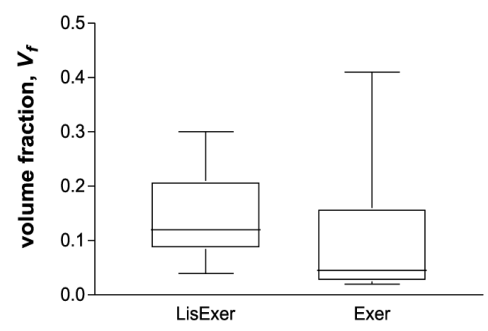

Fig. 3. Box plot comparison of $\mathrm{V}_{\mathrm{f}}$ interstitium between intervention groups. (a) between Lis and Exer, (b) between Lis and LisExer, (c) between LisExer and Exer. $* \mathrm{p}<0.05, * * \mathrm{p}<0.01, * * * \mathrm{p}<0.001$ 
(a)

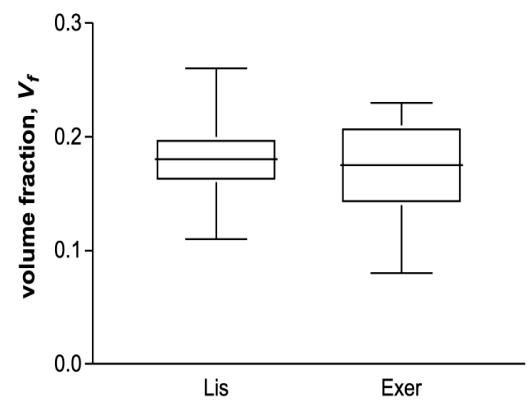

(b)

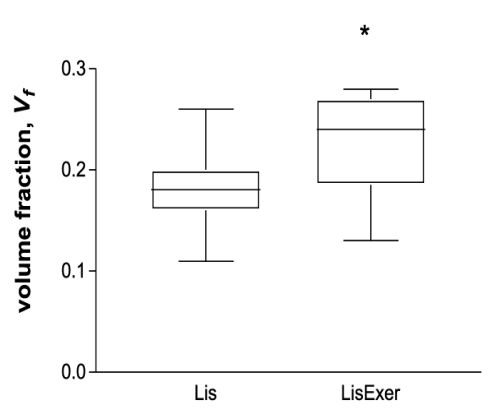

(c)

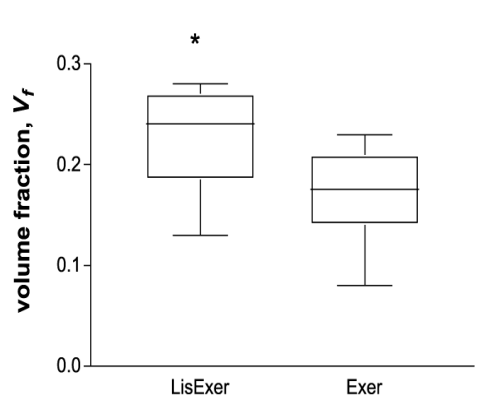

Fig. 4. Box plot comparison of $\mathrm{V}_{\mathrm{f}}$ capillaries between intervention groups. (a) between Lis and Exer, (b) between Lis and LisExer, (c) between LisExer and Exer. $* \mathrm{p}<0.05, * * \mathrm{p}<0.01, * * * \mathrm{p}<0.001$

\section{DISCUSSION}

This study supports earlier findings of increase in capillarity of myocardium in response to exercise and ACE inhibitor treatment in hypertensive rats (Clozel et al., 1989; Barnard et al., 1980; Crisman \& Tomanek).

Volume fraction of muscle was decreased in lisinopril and lisinopril + exercise groups as compared to control group. However, since exercise did not change $V_{f}$ of muscle when compared to control, this suggests that the effect on muscle Vf is mainly due to lisinopril. Chronic treatment with ACE inhibitor cilazapril has been shown to reduced cardiac hypertrophy and improved coronary vascular reserve in the left and right ventricles (Clozel et $a l$.). Hypertrophy in hypertensive rats is thought to be due to excessive laying down of myocardial fibrous tissue by rapidly dividing fibroblasts. The mechanism of reduction in muscle mass in myocardium by ACE inhibitor treatment is thought to be due to inhibition of myocardial fibrosis thereby reversing hypertrophy (Crisman \& Tomanek). The effect of exercise on muscle mass in hypertension is controversial with various studies indicating both hypertrophy as a result of exercise (Barnard et al.) and a reduction in hypertrophy (Hinderliter et $a l$.). There were others however, indicating no significant change in muscle mass due to exercise (Bersohn \& Scheuer, 1977). Our findings here tend to agree with the latter observation. It is thought that the effect of exercise on myocardial mass is mediated via the influence of exercise on collagen transcription ( Samuel et al., 1992). Furthermore, the fact that there was no difference in $V_{f}$ of muscle between lisinopril and lisinopril + exercise groups, in this study indicated that the effect on muscle is largely due to lisinopril and not exercise.
Volume fraction of capillaries showed significant increase in lisinopril, exercise and lisinopril + exercise groups as compared to control indicating that both exercise and lisinopril stimulate capillary growth. It could well be possible however, that the increase in $V_{f}$ capillaries seen in lisinopril is a relative outcome to a decrease in $\mathrm{V}_{\mathrm{f}}$ muscle and not an actual increase in vessels. This therefore produces a net effect of an increase of $\mathrm{V}_{\mathrm{f}}$ capillaries. Indeed it was reported that ACE inhibitor treatment enhances vascularization in the adolescent heart through reductions in myocardial mass, but not capillary growth (Black et al., 2001). However, in the exercise group since there was no significant change in the $V_{f}$ muscle between it and control, this indicates that the increase in $V_{f}$ cap is due to a real increase in capillaries. The mechanism of enhanced capillarity in exercise is thought to involve the bradycardia caused by exercise, which increases myocardial perfusion during diastole. This in return increases blood flow thereby stimulating capillary growth (Hudlicka, 1982). Not surprisingly since both ACE inhibitors and exercise cause an increase in $V_{f}$ capillaries of similar magnitude as compared to sedentary controls, there was no significant difference between the two. However, due to this effect on capillaries the $V_{f}$ of interstitial tissue space was slightly increased though not significantly. When lisinopril and exercise were combined together, they appear to potentiate one another leading to higher $\mathrm{V}_{\mathrm{f}}$ of capillaries than either alone.

It appears from this study that combining moderate exercise with ACE inhibitor lisinopril resulted in a better $V_{f}$ of capillaries and reduction of $\mathrm{V}_{\mathrm{f}}$ muscle than either of the two alone. The outcome of these changes may well be an enhanced cardiac performance in hypertension when the two modalities are combined. 
INUWA, I. M.; HASSAN, M. O. \& ZIADA, A. M. Densidad de volumen del miocardio izquierdo en ratas espontáneamente hipertensas (REH) posterior a la combinación de ejercicios y tratamiento inhibidor de la ACE. Estudio estereológico. Int. J. Morphol., 23(2):157-162, 2005.

RESUMEN: Este estudio fue diseñado para probar los posibles efectos de una combinación de ejercicios y una intervención de terapia farmacológica en las estructuras del miocardio del ventrículo izquierdo, en ratas espontaneamente hipertensivas (SHR).

Ratas de 20 semanas espontáneamente hipertensas $(n=40)$ fueron divididas en cuatro grupos: sedentarias (Sed) y controles, solamente con ejercicio (Ejer), solamente con lisinopril con $20 \mathrm{mg} / \mathrm{kg} /$ día (Lis), y ejercicios + lisinopril (LisEjer). Los ejercicios fueron ejecutados en una máquina de entrenamiento $(5 \mathrm{~m} / \mathrm{min}$.) por 60 minutos/día, 5 días/semana por 10 semanas. Al término de las 10 semanas, las ratas fueron sacrificadas bajo anestesia, el corazón fue detenido en diástole usando procaina intravenosa. Los animales fueron perfundidos a través de la parte abdominal de la aorta, usando solución de Karnovsky ( $\mathrm{pH}$ 7.24). El corazón fue removido y tanto al ventrículo izquierdo como al septo interventricular se les realizaron cortes seriados de $3 \mu \mathrm{m}$. Una pieza fue seleccionados al azar, y sumergida en resina JB4. Fueron obtenidas 6 secciones de cada bloque y luego teñidas con azul de toluidina:fucsina ácida. Las mediciones de fracción volumétrica (Vf) del miocardio, capilares, e intersticio fueron obtenidas usando un software de estereología (Histometrix MIL6 Kinetic imaging Ltd.).

El promedio $\mathrm{V}_{\mathrm{f}}$ de capilares en el grupo Sed, fue $0.114 \pm 0.01(\mathrm{SEM})$. Éste fue significativamente mayor en el grupo LisExer. El $\mathrm{V}_{\mathrm{f}}$ de músculo en Sed fue $0.795 \pm 0.02$ (SEM). Éste fue significativamente menor en Lis pero no varió en el grupo Ejer. $V_{f}$ capilares fue significativamente alto en LisExjr, si es comparado con los grupos Lis o Ejer $(\mathrm{p}<0.05)$. En $\mathrm{V}_{\mathrm{f}}$ músculo no hubo diferencias entre los grupos LisEjer y Lis. El resultado de estos cambios pudo deberse a un mejor funcionamiento cardiaco en ratas hipertensa,s producto de ejercicios combinados y tratamiento con inhibidor ACE, que en aquellos en que se efectó un solo procedimiento.

PALABRAS CLAVE: Miocardio; Hipertrofia; Inhibidor-ACE; Fracción de volumen; Ejercicio.

\section{REFERENCES}

Anversa, P.; Levicky, V.; Beghi, C.; McDonald, S. L. \& Kikkawa Y. Morphometry of exercise-induced right ventricular hypertrophy in the rat. Circ. Res., 52: 5764, 1983.

Barnard, R. J.; Duncan, H. W.; Baldwin, K. M.; Grimditch, G. \& Buckberg, G. D. Effects of intensive exercise training on myocardial performance and coronary blood flow. J. Appl. Physiol, Respiratory, Environmental and Exercise Physiology, 49(3):444-9, 1980.

Bersohn, M. M. \& Scheuer, J. Effects of physical training on end-diastolic volume and myocardial performance of isolated rat hearts. Circ. Res., 40(5):510-6, 1977.

Black, M. J.; Bertram, J. F.; Johnston, C. I. Effect of angiotensin-converting enzyme inhibition on myocardial vascularization in the adolescent and adult spontaneously hypertensive rat. J. Hyperten., 19(4):785-94, 2001.

Clozel, J. P.; Kuhn, H. \& Hefti, F. Effects of chronic ACE inhibition on cardiac hypertrophy and coronary vascular reserve in spontaneously hypertensive rats with developed hypertension. J. Hypertens, 7:267-75, 1989.

Crisman, R. P. \& Tomanek, R. J. Exercise training modifies myocardial mitochondria and myofibril growth in spontaneously hypertensive rats. Am. J. Physiol., 248:H8-14, 1985.

Der_Sarkissian, S.; Marchand, E. L.; Duguay, D.; Hamet, P. \& deBlois D. Reversal of interstitial fibroblast hyperplasia via apoptosis in hypertensive rat heart with valsartan or enalapril. Cardiovasc. Res., 57:775-83, 2003.

Heringer-Walther, S.; Batista, E. N.; Walther, T.; Khosla, M. C.; Santos, R. A. S. \& Campagnole-Santos, M. J. Baroreflex Improvement in SHR After ACE Inhibition involves angiotensin. Hypertension. 37:1309, 2001.

Himeno, E.; Nishino, K.; Nakashima, Y; Kuroiwa, A. \& Ikeda M. Weight reduction regresses left ventricular mass regardless of blood pressure level in obese subjects. Am. Heart. J., 131:313-9, 1996.

Hinderliter, A.; Sherwood, A.; Gullette, E. C.; Babyak, M.; Waugh, R.; Georgiades, A. \& Blumenthal, J. A. Reduction of left ventricular hypertrophy after exercise and weight loss in overweight patients with mild hypertension. Arch. Intern. Med., 162:1333-9, 2002.

Hudlicka, O. Growth of capillaries in skeletal and cardiac muscle. Circ. Res., 50:451-61, 1982. 
Lazar, H. L.; Bao, Y.; Rivers, S.; Colton, T.; Bernard, S. A. High tissue affinity angiotensin-converting enzyme inhibitors improve endothelial function and reduce infarct size. Ann. Thoracic Surg., 72:548, 2001.

Mancia, G.; Giannattasio, C. \& Grassi, G. Current antihypertensive treatment: can we do better? Am. J. Hyperten., 12(1):131-8, 1999.

Mattfeldt, T.; Mall, G.; Garehbaghi, H. \& Moller, P. Estimation of surface area and length with the orientator. J. Microsc., 159:301-17, 1990.

Samuel, J. L.; Marotte, F.; Contard, F. et al. Time course of fibronectin mRNAs accumulation during the development of cardiac hypertrophy induced by pressure overload in the rat J. Mol. Cell Cardiol., 24:(Suppl. 1):62, 1992.
Correspondence to: Dr. Ibrafim M. Inuwa Department of Human and Clinical Anatomy, Sultan Qaboos University PO Box 35. Al Khod 123.

Muscat,

SULTANATE OF OMAN

Telephone: +96824415176

Fax: +96824415175

Email: ibrafim1@squ.edu.om

Received : 25-02-2005

Accepted: 17-05-2005 